\title{
ПРАВА ЧЕЛОВЕКА
}

\section{Некоторые международно-правовые гарантии обеспечения личных прав и свобод человека и гражданина в субъектах Российской Федерации}

Босхомджиева Г.Г.*

За последние годы в Российской Федерации был принят целый ряд законов, усиливающих гарантии соблюдения прав граждан, были ратифицированы основополагающие международные соглашения в области прав человека. Модель демократического государства, воплощаемая в России, базируется на ряде основополагающих идей и принципов, признаваемых мировым сообществом, и центральное место отводит неотчуждаемым, неотъемлемым правам человека. Специальные механизмы и процедуры и международное регулирование внутригосударственных механизмов защиты прав личности призваны стать дополнительной гарантией выполнения государствами их международных обязательств.

В рамках данной статьи под гарантиями обеспечения личных прав граждан мы будем понимать условия и нормативно-правовые средства обеспечения законности, средства, способствующие их охране, защите и восстановлению, выражающиеся в деятельности государственных и общественных органов и организаций в области охраны правопорядка Российской Федерации и субъектов Российской Федерации. Следует отметить, что международные гарантии прав и свобод, так же как

\footnotetext{
* Босхомджиева Гиляна Герасимовна - заместитель министра экономики Республики Калмыкия, Министерство экономики Республики Калмыкия.
} 
и внутригосударственные, можно разделить на материальные и процессуальные. Материальные гарантии - это нормы международного права, устанавливающие права человека и его свободы. Процессуальные - нормы, устанавливающие процедуру их защиты.

В ст. 17 Конституции Российской Федерации заложен важнейший принцип: «В Российской Федерации признаются и гарантируются права и свободы человека и гражданина согласно общепризнанным принципам и нормам международного права...», который должен согласоваться со ст. 55 Конституции Российской Федерации: «В Российской Федерации не должны издаваться законы, отменяющие или умаляющие права и свободы человека и гражданина». Кроме того, следует учитывать положения ч. 4 ст. 15 Конституции РФ. Статья 15 декларирует приоритет предписаний норм международных договоров перед положениями законов Российской Федерации. Рассматривая вопрос о том, какие международные соглашения могут применяться на территории РФ, В.С. Хижняк отмечает, что в ст. 23 Федерального закона «О международных договорах Российской Федерации» указывается на возможность временного применения нератифицированных договоров, ратификация которых по законодательству Российской Федерации является обязательной. Такие договоры получили в юридической литературе название «временно самоисполнимые» ${ }^{1}$. На вопрос о том, входят ли проблемы защиты прав человека только во внутреннюю компетенцию государства, не может быть однозначного ответа. Большинство авторитетных юристов-международников утверждают, что по крайней мере запрет таких действий, как рабство и работорговля, геноцид, апартеид, пытки, массовые убийства, длительное произвольное содержание под стражей, систематическая расовая дискриминация, стал обычной нормой международного права ${ }^{2}$. Таким образом, можно сделать вывод, что если непосредственная регламентация прав человека, их защита и обеспечение осуществляются внутренним правом, то содержание норм о правах человека должно согласовываться с международным правом.

В Российской Федерации действует система внутригосударственных гарантий прав человека, а среди них не последнее место занимают

${ }^{1}$ См.: Хижняк В.С. Взаимодействие национального права России и международного права: конституционные основы. Саратов, 2002. С. 70.

2 CM.: Schachter O. International Law in Theory and Practice. R.D.C. 1982. V. 178-V. P.336; D, Amato A. International Law: Process and Prospect. N.Y. 1987. P. 145. 
гарантии, установленные на уровне субъектов Федерации. Конституции (уставы) большинства субъектов Федерации по аналогии с федеральной Конституцией содержат указание на признание международных норм в качестве составной части своей правовой системы. Так, общепризнанные принципы и нормы международного права являются составной частью правовой системы Республики Татарстан (ч. 4 ст. 24). Республика Бурятия соблюдает общепризнанные принципы и нормы международного права (ст. 13). Статья 12 Конституции Республики Хакасии гарантирует человеку и гражданину общепризнанные права и свободы, предусмотренные Конституцией Российской Федерации.

Международное право делает больший акцент на гарантиях прав, относящихся к группе личных и политических. На региональном уровне самой эффективной организацией, действующей в сфере защиты прав и свобод человека, является, на наш взгляд, Совет Европы.

С.А. Глотов, В.Д. Мазаев ${ }^{3}$ указывают, что система прав человека, установленная Европейской Конвенцией о защите прав человека и основных свобод ${ }^{4}$ и дополнительными протоколами ${ }^{5}$ к ней, состоит

${ }^{3}$ См.: Глотов С.А., Мазаев В.Д. Современная концепция прав человека в принципах и нормах Совета Европы. Путеводитель по специальному лекционному курсу для студентов / Институт Национальной Стратегии реформ. М., 2001. С. 135-144.

${ }^{4}$ См.: Конвенция о защите прав человека и основных свобод ETS N 005 (Рим, 4 ноября 1950 г.) (с изм. и доп. от 21 сентября 1970 г., 20 декабря 1971 г., 1 января 1990 г., 6 ноября 1990 г., 11 мая 1994 г.) // Бюллетень международных договоров, март 2001 г., № 3.

${ }^{5}$ См.: Протокол № 1 к Конвенции о защите прав человека и основных свобод ETS N 009 (Париж, 20 марта 1952 г.) // Бюллетень международных договоров, март 2001 г., № 3. Протокол № 2 к Конвенции о защите прав человека и основных свобод «О наделении Европейского Суда по правам человека компетенцией выносить консультативные заключения ETS» № 044 (Страсбург, 6 мая 1963 г.) // Бюллетень международных договоров, июль 1998 г., № 7

Протокол № 4 к Конвенции о защите прав человека и основных свобод «Об обеспечении некоторых иных прав и свобод помимо тех, которые уже включены в Конвенцию и Протокол № 1 к ней» ETS № 046 (Страсбург, 16 сентября 1963 г.) // Бюллетень международных договоров, март 2001 г., №3.

Протокол № 6 к Конвенции о защите прав человека и основных свобод «Относительно отмены смертной казни ETS» № 114 (Страсбург, 28 апреля 1983 г.) // Текст Протокола официально опубликован не был // Справочная правовая система «Гарант».

Протокол № 7 к Конвенции о защите прав человека и основных свобод ETS N 117 (Страсбург, 22 ноября 1984 г.) // Бюллетень международных договоров, март 2001 г., № 3 .

Протокол № 11 к Конвенции о защите прав человека и основных свобод «О реорганизации контрольного механизма, созданного в соответствии с Конвенцией» ETS 
из личных прав (ст. 2, 3, 4, 5, 8 и 12 Конвенции, ст. 1, 2 Протокола № 6 к ЕКПЧ); юридических прав (ст. 5, 6, 7, 13, 14, 15, 16, 17, 18, 19 ЕКПЧ); гражданских прав (ст. 11 Конвенции, ст. 2, 3, 4 Протокола № 4 к ЕКПЧ); политических прав граждан (ст. 10, 11 ЕКПЧ, ст. 3 Протокола № 1 к ЕКПЧ); имущественных (ст. 8 ЕКПЧ, ст. 1 Протокола № 1 к ЕКПЧ) и духовных (ст. 9, 10 ЕКПЧ) Протокол № 4 от 16.09.1963 г:: запрещение лишения свободы за долги (ст. 1); свобода передвижения (ст. 2); запрещение высылки граждан (ст. 3); запрещение массовой высылки иностранцев (ст. 4).

Основные права и свободы должны быть едины на всей территории государства, а их обеспечение и защита являются предметом федерального законодательства и принимаемых в соответствии с ним нормативных правовых актов местных органов власти 6 . Коллективные права граждан вытекают из прав и свобод личности и не должны им противоречить. Государство и группа лиц не могут ликвидировать какие-либо права, закрепленные в Конвенции, под предлогом защиты коллективных прав.

В международном праве именно судебной защите уделяется главное внимание в механизме защиты прав индивида. Данный факт подтверждается рядом рекомендательных документов, прямо или косвенно касающихся судебного механизма либо регулирующих вопросы правового положения лиц, относящихся к участникам судопроизводства. Важность судебной защиты как механизма, ответственного за принятие окончательных решений «по вопросам жизни и смерти, свободы, прав, обязанностей и собственности граждан», особо подчеркивается в каждом из основных документов о правах человека. Право на судебную защиту прав и свобод индивида в общем виде закрепляет ст. 8 Всеобщей декларации: каждый имеет право на эффективное восстановление в правах компетентными национальными судами в случаях

№ 155 (Страсбург, 11 мая 1994 г.) // Бюллетень международных договоров, декабрь 1998 г., № 12.

Протокол № 12 к Конвенции о защите прав человека и основных свобод ETS № 177 (Рим, 4 ноября 2000 г.) // Журнал «Совет Европы и Россия». 2001. № 1.

Протокол № 13 к Европейской конвенции о защите прав человека и основных свобод относительно отмены смертной казни в любых обстоятельствах ETS № 187 (Вильнюс, 3 мая 2002 г.) // Московский журнал международного права. 2004. № 2.

6 См.: Европейская конвенция о защите прав и основных свобод и дополнительные протоколы. М., 1996. С. 7-10. 
нарушения его основных прав, предоставленных ему конституцией или законом ${ }^{7}$.

По своему содержанию международно-правовая защита прав и свобод граждан фактически переросла в самостоятельный институт международного права ${ }^{8}$. Особенностью международно-правовой защиты прав и свобод граждан является то, что она применяется в случае, если гражданин исчерпал возможности сатисфакции посредством обращения в национальные правоохранительные органы и не нарушил процедуру обращения в международную правозащитную инстанцию.

В Международном пакте о гражданских и политических правах $1966 \Gamma^{9}$. перечень органов, призванных защищать и восстанавливать нарушенные права физических лиц, уже не ограничивается национальными судами: право на защиту должно обеспечиваться «компетентными судебными, административными или законодательными властями или любым другим компетентным органом, предусмотренным правовой системой государства» (п. “b” ч. 3 ст. 2 Пакта).

Представляется, что Российской Федерации необходимо совершенствовать иные механизмы защиты, кроме судебного механизма, обеспечивать их действенность и работу. Это касается потенциальных возможностей административных, правоохранительных органов и общественных объединений. Тем более что помимо права на судебную защиту (ст. 46) Конституция РФ закрепляет право каждого защищать свои права и свободы всеми способами, не запрещенными законом (ст. 45 Конституции РФ).

Таким образом, мы приходим к выводу, что к настоящему времени не только сложилась и действует система международно-правовой защиты прав граждан, но и совершенствуется механизм юридических гарантий реализации и защиты прав человека.

Наличие международных процедур и механизмов, регламентирующих защиту прав и свобод человека, не означает, что

7 См.: Всеобщая декларация прав человека (принята на третьей сессии Генеральной Ассамблеи ООН резолюцией 217 А (III) от 10 декабря 1948 г.) // Библиотечка Российской газеты. Вып. № 22-23. 1999.

8 См.: Глущенко П.П. Конституционные права и свободы граждан в Российской Федерации: теоретические и организационно-практические вопросы социально-правовой защиты. СПб., 1998. С. 274.

9 См.: Международный пакт о гражданских и политических правах (Нью-Йорк, 19 декабря 1966 г.) // Сборник действующих договоров, соглашений и конвенций, заключенных с иностранными государствами. М., 1978. Вып. XXXII. С. 44. 
внутригосударственные средства должны быть обойдены либо поставлены на второй план. Надо учитывать, что основной механизм защиты прав российского гражданина - внутригосударственный, и он должен действовать достаточно эффективно. Поэтому одной из важнейших задач российского федеративного государства является обеспечение единых стандартов осуществления и защиты прав человека на всей территории страны - во всех субъектах Российской Федерации. Законность на территории России должна быть единой, так же как права и свободы человека и гражданина. Никто не имеет права ущемлять права и свободы человека, зафиксированные в Конституции страны и в федеральном законодательстве. Это одно из непременных условий упорядочения российской государственности, обеспечения прав личности на всей территории страны.

Для реализации международных гарантий защиты прав человека на национальном уровне, на наш взгляд, необходимо:

1) создать эффективно работающий внутригосударственный механизм защиты прав и свобод человека;

2) создать систему гарантий реализации принимаемых законов, поскольку на сегодняшний день основные права и свободы человека и гражданина перестали быть чисто внутренним делом государства;

3) активнее использовать возможности международного контроля за соблюдением государственных международных стандартов прав и свобод человека, с тем чтобы своевременно предупреждать массовые нарушения прав и свобод граждан, национальных меньшинств;

4) объединить усилия государств, межгосударственных и межправительственных социальных институтов и структур, национальных правозащитных инстанций и индивидуальных частных лиц, занимающихся правозащитной деятельностью, для наработки методик, механизмов, средств, способов и методов организации и осуществления социально-правовой помощи и защиты различных категорий граждан;

5) значительно активизировать международно-правовую подготовку, информированность всех категорий населения России, в том числе школьной и студенческой молодежи, о международных правозащитных организациях, для чего важно создание центров социально-правовой помощи (платных и бесплатных);

6) предусмотренная Конституцией государственная система, призванная обеспечивать гарантии прав и свобод человека, не справляется в должной мере со своими задачами. Об этом свидетельствуют 
многочисленные нарушения прав человека, отсутствие необходимых механизмов и условий для реализации многих конституционно закрепленных прав человека, трудности в защите нарушенных прав граждан, отсутствие в ряде случаев необходимой законодательной базы и многое другое;

7) усилить взаимодействие субъектов Федерации и Федерации в целом с целью реализации международных гарантий защиты прав человека на национальном уровне.

\section{On International Legal Guarantees for Ensuring Personal Rights and Freedoms in the Subjects of the Russian Federation (Summary)}

Gilyana G. Boskhomdzhieva*

The article "On International Legal Guarantees for Ensuring Personal Rights and Freedoms in the Subjects of the Russian Federation" deals with the present system of human rights guarantees: international and domestic ones (that of the Russian Federation) and also guarantees constituted on the Russian regional level. By analogy with the Federal Constitution, constitutions (charters) of most constituent territories of the Russian Federation declare of their recognition of international standards as an inseparable part of their legal system. International law lays special emphasis on personal and political rights guarantees. The author concludes that one of the main objectives of the Russian federative state is to provide unified standards for human rights pursuance and protection on the whole of its territory - in all its constituent territories.

* Gilyana G. Boskhomdzhieva - deputy minister of economy of the Kalmyk Republic, Ministry of Economy of the Kalmyk Republic. 